\title{
Influence of cooling mode in relation to casting and extrusion parameters on mechanical properties of AA6082
}

\section{Vpliv načina ohlajanja v povezavi s parametri ulivanja in iztiskanja na mehanske lastnosti zlitine AA6082}

\author{
Simon Malej ${ }^{*}$, Milan Terčelj ${ }^{2}$, Iztok Peruš ${ }^{2,3}$, Goran Kugler ${ }^{2}$ \\ ${ }^{1}$ Institute of Metals and Technology, Lepi pot 11, 1000 Ljubljana, Slovenia \\ ${ }^{2}$ Department for Materials and Metallurgy, Faculty for Natural Sciences and Engineering, University of Ljubljana, Aškerčeva 12, \\ 1000 Ljubljana, Slovenia \\ ${ }^{3}$ Transportation Engineering and Architecture, Faculty of Civil Engineering, University of Maribor, Smetanova ulica 17, \\ 2000 Maribor, Slovenia \\ *Email: simon.malej@imt.si
}

\begin{abstract}
In this study, conditional average estimator neural networks (CAE NNs) were used for an analysis of the common influences of the cooling mode in relation to the ram speed, extrusion ratio, casting speed and casting temperature on the yield strength and the elongation of an extruded profile made from aluminium alloy (AA)6082. The obtained results from the analysis revealed very complex relationships between these parameters. In order to maximise the values for the yield strength and the elongation, the values for the ram speed, extrusion ratio, casting speed and casting temperature should be optimised in relation to the mode of cooling.
\end{abstract}

Key words: AA6082, intermetallic phases, hot extrusion, mechanical properties, neural networks

\section{Izvleček}

V tem delu smo uporabili CAE (ang. conditional average estimator, slo. cenilka pogojnega povprečja) nevronske mreže za analizo skupnega vpliva načina ohlajanja v povezavi s hitrostjo bata, iztiskalnim razmerjem, hitrostjo ulivanja in temperaturo ulivanja na mejo tečenja in raztezek iztiskanega profila iz aluminijeve zlitine 6082 . Dobljeni rezultati iz analize so pokazali kompleksen vpliv parametrov na mejo tečenja in raztezek. Da lahko izboljšamo vrednosti meje tečenja in raztezka, moramo vrednosti za hitrost bata, iztiskalnega razmerja, hitrosti ulivanja in temperature ulivanja optimizirati v povezavi z načinom ohlajanja.

Ključne besede: AA6082, intermetalne faze, vroče izstiskavanje, mehanske lastnosti, nevronske mreže 


\section{Introduction}

The use of aluminium alloys (AAs) in the construction and transportation industries has increased in the past decade because of the increasing demand for lightweight constructions and fuel-efficient vehicles $[1,2]$. AAs have lower density and medium strength, but compared with construction steels, they have a higher ratio of yield strength to density. So any increase in the mechanical strength would be beneficial to the AA.

There are various steps in the manufacture of AA6082, i.e. melting, casting, homogenisation, extrusion and ageing. In every step of the manufacturing process, the chemical composition and the process parameters have a very complex influence on the final mechanical properties [3-10]. One of these steps is the homogenisation process, which is a crucial heat treatment before the extrusion process for AA production $[11,12]$. After casting, the microstructure is not suitable for extrusion and has an inhomogeneous chemical composition, $\alpha$-Al dendrites with various phases at the borders or in the interdendritic areas. These are usually $\beta$ - $\mathrm{Al}_{5} \mathrm{FeSi}, \alpha-\mathrm{Al}(\mathrm{FeMn}) \mathrm{Si}, \mathrm{Al}_{9} \mathrm{Mn}_{3} \mathrm{Si}$ and $\mathrm{Mg}_{2} \mathrm{Si}$, either as single constituents or as complex eutectic clusters $[13,14]$. During the homogenisation process, phases such as $\mathrm{Mg}_{2} \mathrm{Si}$ dissolve, or transform and change their shape, e.g. needles of $\beta-\mathrm{Al}_{5} \mathrm{FeSi}$ change into spheres of $\alpha$ - $\mathrm{Al}(\mathrm{FeMn})$ Si phase. The important part after homogenisation is cooling; a slow cooling speed could lead to the precipitation of $\mathrm{Mg}_{2} \mathrm{Si}$. The second-phase particles in the Al matrix of AA could influence the deformation process [15].

A lot of parameters have a complex influence on the final mechanical properties. But, for large numbers of parameters, the standard experimental methods are not suitable for research of their complex influences on the mechanical properties and are time consuming. For an analysis of the complex influence of the process parameters on the mechanical properties, data collected during the production of AA6082 can be used. The most suitable method for this kind of analysis is that of artificial intelligence, e.g. neural networks. The use of neural networks in metallurgy is relatively new, but some pioneers are already using them [16-20]. In this study, conditional average estimator neural networks (CAE NNs) were used for an analysis of the cooling mode in relation to the casting and extrusion parameters and their effects on the final mechanical properties.

\section{Experimental}

\section{CAE NN analysis}

In this study, CAE NN was used to analyse the complex influences of the cooling mode in relation to the process parameters on the yield strength and elongation. The method is especially useful for analysing the unknown influences between various input and output parameters [21]. The observed sample is described by $N$ variables, in our case, the process parameters and the mechanical properties. Each sample is mathematically described by the model vector $X_{n}$ (Equations 1 and 2). For a complete and correct description of a certain problem, a large quantity of samples is needed. Therefore, the whole phenomenon is described by $n$ set of model vectors, which represent a database (Equation 1).

$\left\{X_{1}, \ldots, X_{n}, \ldots, X_{N}\right\}$

$X_{n}=\left\{b_{n 1}, \ldots, b_{n l}, \ldots, b_{n D}, c_{n 1}, \ldots, c_{n k}, \ldots, c_{n M}\right\}$

Each model vector is composed of two partial vectors $B_{n}$ (Equation 3 ) and a truncated vector $C_{n}$ (Equation 4). The concatenation of both $B_{n}$ and $C_{n}$ vectors forms a complete model vector (Equation 2).

$$
\begin{aligned}
& B_{n}=\left\{b_{n 1}, \ldots, b_{n l}, \ldots, b_{n D}\right\} \\
& C_{n}=\left\{c_{n 1}, \ldots, c_{n k}, \ldots, c_{n M}\right\}
\end{aligned}
$$

The prediction vector is also formed of two partial vectors; vector $B$ (Equation 5) and an unknown complementary vector (Equation 6).

$B=\left\{b_{1}, \ldots, b_{l}, \ldots, b_{D}\right\}$

$\hat{C}_{n}=\left\{c_{1}, \ldots, c_{k}, \ldots, c_{M}\right\}$ 
Table 1: Minimum, maximum and average values of chemical composition for AA6082, wt\%.

\begin{tabular}{ccccccccc} 
& Fe & Si & Mn & Mg & Cu & Zn & Cr & Ti \\
\hline Min. & 0.22 & 0.80 & 0.4 & 0.66 & 0.02 & 0.02 & 0.01 & 0.01 \\
\hline Max. & 0.44 & 1.24 & 0.59 & 0.90 & 0.10 & 0.13 & 0.17 & 0.04 \\
\hline Avg. & 0.31 & 0.89 & 0.47 & 0.75 & 0.06 & 0.04 & 0.04 & 0.02 \\
\hline
\end{tabular}

Notes: Min., minimum; Max., maximum; Avg. average.

The method estimates the unknown complementary vector using a probability density function (Equations 7 and 8), which uses the model vector $X_{N}$ and the truncated vector $B$. In this research, the yield strength is estimated from the database and the known process parameters. The Gaussian function (Equation 9) was chosen as a weight function, which is centred at each $n$th model vector, to obtain the influence of the $n$th model vector at the point of the prediction vector. In Equation 9, $w$ is defined as a weight function ( 0.15 in our case), and $D$ is defined as the number of input variables.

$\hat{C}_{k}=\sum_{n=1}^{N} A_{n} \cdot C_{n k}$

$A_{n}=\frac{a_{n}}{\sum_{i=1}^{N} a_{i}}$

$a_{n}=\frac{1}{2(\pi)^{D / 2} w^{D}} \exp \left[-\sum_{l=1}^{D} \frac{\left(b_{l}-b_{n l}\right)^{2}}{2 w^{2}}\right]$

Equation 9 calculates the intermediate result in the computational process and describes the influence of all the samples and how well they are spread over the problem space. The probability density function $(\hat{p})$ describes the accuracy of the prediction. The higher the number, the more probable the prediction is and vice versa.

$\hat{p}=\frac{1}{N} \sum_{n=1}^{N} a_{n}$

The results are presented on contour diagrams, with the values of the process parameters on the vertical and horizontal axes. There are two types of values on each contour diagram: the yield strength or elongation, and the probability density function $\hat{p}$. The reliability of the prediction usually has values in the range from 0.5 to $\geq 5$. The values for the yield strength and elongation wherein the reliability is $<0.5$ are generally less accurate.

\section{Database}

The data were collected at the Impol Company (Slovenska Bistrica, Slovenia) from different stages of the production process, which involves continuous casting, homogenisation, extrusion and finally ageing. The collected database consists of 3,968 model vectors, which contain data for the process parameters (such as casting speed, casting temperature, extrusion ratio and ram speed), as well as the yield strength and the elongation as the output parameters. Table 1 shows the minimum, maximum and average values for the chemical composition. The process parameters considered in the analysis (Table 2) are the ram speed, extrusion ratio, rate of casting and casting temperature. In Table 2, there are also the minimum, maximum and average values of the yield strength and elongation. After homogenisation, the ingots were cooled in two ways. The first way was cooling by water for 3-4 $\mathrm{min}(\mathrm{PH})$. The second way was air-cooling in a chamber with ventilators for $2 \mathrm{~h}$ (HH1).

\section{Results and discussion}

The results of the analysis are presented in contour diagrams in Figures 1-4. In the following analysis, only those results with prediction reliability higher than 0.5 were considered. The prediction reliability is presented as thin lines in Figures 1-4. On the other hand, the yield strength and the elongation are presented as 

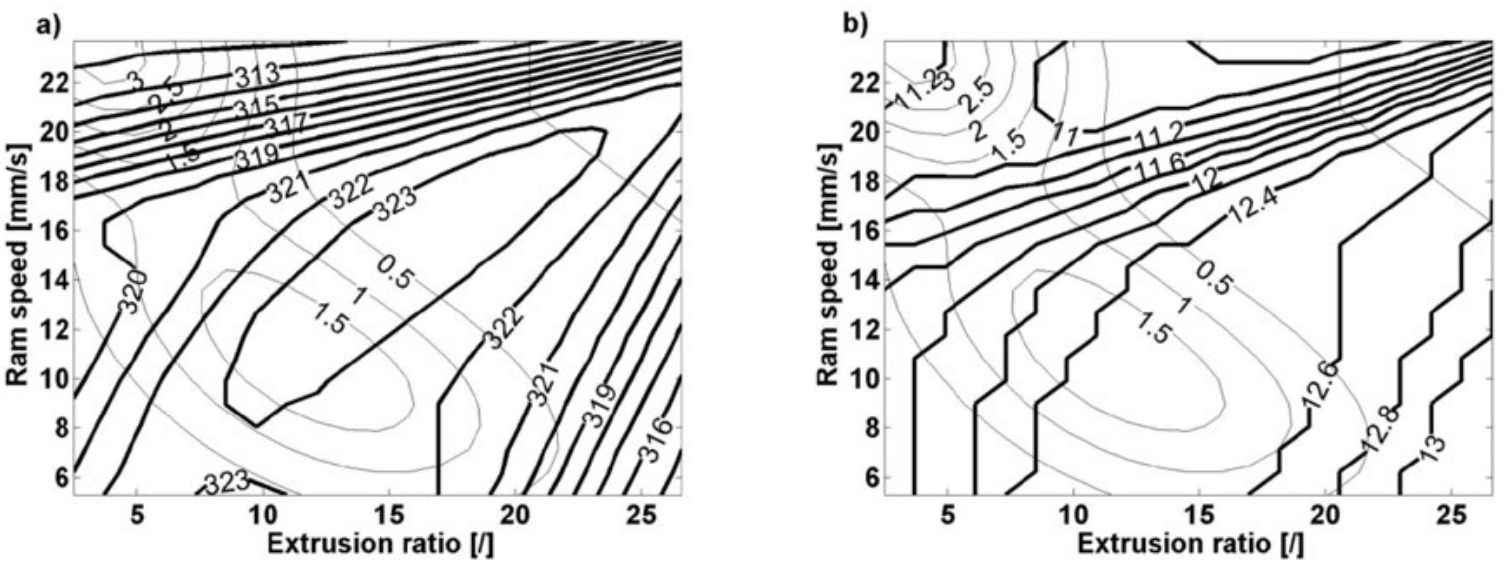

Figure 1: Common influence of ram speed and extrusion ratio on (a) yield strength and (b) elongation with PH cooling mode.

Table 2: Minimum, maximum and average values for extrusion ratio, ram speed, casting speed, casting temperature, yield strength and elongation.

\begin{tabular}{ccccccc} 
& $\begin{array}{c}\text { Extrusion } \\
\text { ratio [/] }\end{array}$ & $\begin{array}{c}\text { Ram speed } \\
{[\mathbf{m m} / \mathbf{s}]}\end{array}$ & $\begin{array}{c}\text { Rate of } \\
\text { casting } \\
{[\mathbf{m m} / \mathbf{s}]}\end{array}$ & $\begin{array}{c}\text { Casting } \\
\text { temperature }\left[{ }^{\circ} \mathbf{C}\right]\end{array}$ & $\begin{array}{c}\text { Yield } \\
\text { strenght } \\
{[\mathbf{M P a}]}\end{array}$ & $\begin{array}{c}\text { Elongation } \\
{[\%]}\end{array}$ \\
\hline Min. & 2.5 & 5.3 & 7.2 & 690 & 243.23 & 7.20 \\
\hline Max. & 26.6 & 23.7 & 7.5 & 730 & 365.82 & 17.39 \\
\hline Avg. & 9.1 & 15.5 & 7.4 & 724 & 319.89 & 11.97 \\
\hline
\end{tabular}

Notes: Min., minimum; Max., maximum; Avg. average.

thick lines in Figures 1-4. By comparing the different modes of cooling in Figures 1-4, the complex influence of the cooling mode in relation to the values for the ram speed, extrusion ratio, casting speed and casting temperature on the yield strength and elongation can be seen. In Figure 1, the common influence of the ram speed and the extrusion ratio on the yield strength and elongation of the $\mathrm{PH}$ cooling mode can be seen. From an extrusion ratio of 5.0 and a ram speed of $22 \mathrm{~mm} / \mathrm{s}$, the values for the yield strength (Figure 1a) increase with increasing values for the extrusion ratio and decreasing values for the ram speed. For an extrusion ratio of 15 and a ram speed of $14 \mathrm{~mm} / \mathrm{s}$, the values for the yield strength reach maximum values of approximately 323-324 MPa. From this point, the values for the yield strength decrease with increasing values for the ram speed and decreasing values for the extrusion ratio. The values for the elongation (Figure 1b) generally increase from an extrusion ratio of 5 and a ram speed of $22 \mathrm{~mm} / \mathrm{s}$, with increasing values for the extrusion ratio and decreasing values for the ram speed. The maximum values for elongation (12.6-12.8\%) in the area of high prediction reliability can be seen for an extrusion ratio of 20 and a ram speed of $7 \mathrm{~mm} / \mathrm{s}$.

In Figure 2, the common influence of the ram speed and the extrusion ratio on the yield strength and the elongation of the HH1 cooling mode can be seen. The values for the yield strength (Figure 2a) increase from an extrusion ratio of 3 and a ram speed of $23 \mathrm{~mm} / \mathrm{s}$ with increasing values for the extrusion ratio and decreasing values for the ram speed, to an extrusion ratio of 17 and a ram speed of $14 \mathrm{~mm} / \mathrm{s}$. At this point, the values for the yield strength are a maximum in the range 326-327 MPa. From an extrusion ratio of 17 and a ram speed of $14 \mathrm{~mm} / \mathrm{s}$, the values for the yield strength decrease with increasing values for the extrusion ratio and decreasing values for the ram speed, to an extrusion ratio of 25 and a ram speed of $6 \mathrm{~mm} / \mathrm{s}$. In this case also, the values for the elongation increase (Figure $2 \mathrm{~b}$ ) with increasing values for the extrusion ratio and decreasing values for the ram speed. But at an extrusion 

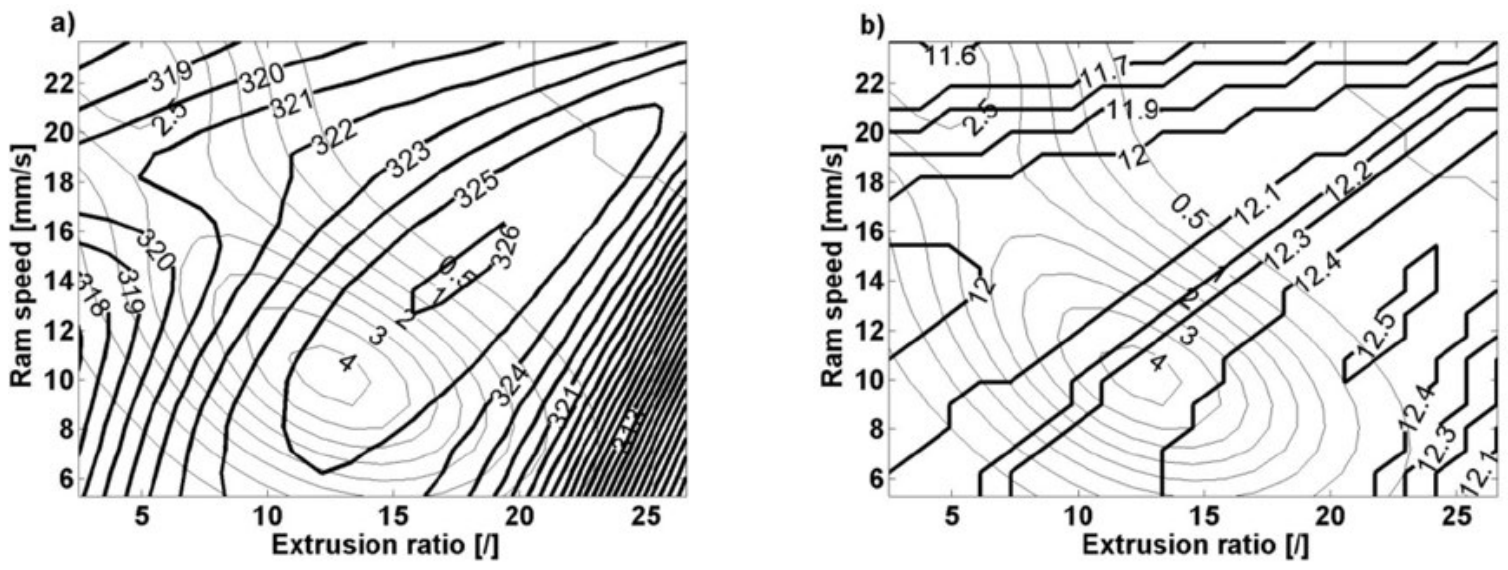

Figure 2: Common influence of ram speed and extrusion ratio on (a) yield strength and (b) elongation with HH1 cooling mode.
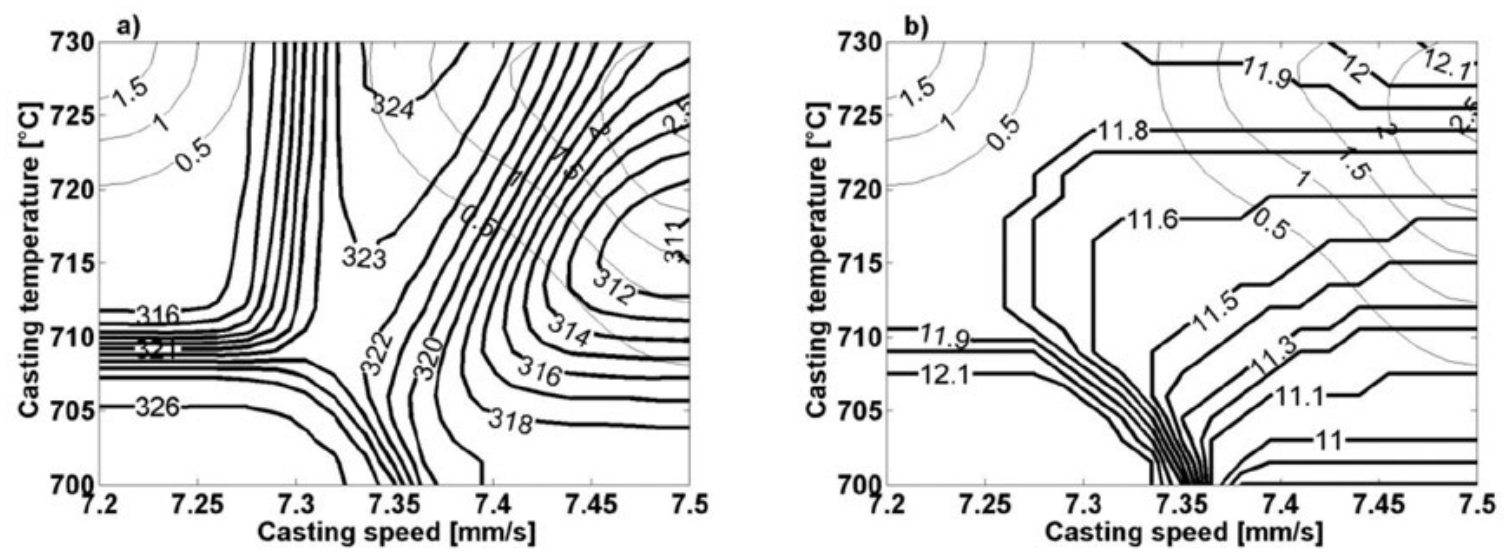

Figure 3: Common influence of casting speed and casting temperature on (a) yield strength and (b) elongation with PH cooling mode.

ratio of 22 and a ram speed of $11 \mathrm{~mm} / \mathrm{s}$, the values for the elongation reach a maximum value in the range of $12.5-12.6 \%$. From the extrusion ratio of 22 and the ram speed of $11 \mathrm{~mm} / \mathrm{s}$, with increasing values for the extrusion ratio and decreasing values for the ram speed, the values for the elongation decrease.

The common influence of the casting speed and casting temperature on the yield strength and elongation in relation to the $\mathrm{PH}$ cooling mode can be seen in Figure 3. In the area of the diagram to a casting speed of approximately $7.33 \mathrm{~mm} / \mathrm{s}$, the values for the yield strength (Figure 3a) decrease with increasing values for the casting temperature and constant values for the casting speed. In the area of the diagram above a casting speed of $7.35 \mathrm{~mm} / \mathrm{s}$, the values for the yield strength decrease with increasing values for the casting speed and constant values for the casting temperature. At a casting speed of $7.35 \mathrm{~mm} / \mathrm{s}$ and a casting temperature of $730^{\circ} \mathrm{C}$, the values for the yield strength are a maximum and reach approximately 324-325 $\mathrm{MPa}$. As in the case of the yield strength (Figure 3a), in the area of the diagram up to $7.26 \mathrm{~mm} / \mathrm{s}$, the values for elongation (Figure $3 \mathrm{~b}$ ) also decrease with increasing values for the casting temperature and constant values for the casting speed. But in the area of the diagram above $7.3 \mathrm{~mm} / \mathrm{s}$, the values for the elongation increase with increasing values for the casting temperature and constant values for the casting speed. At the casting speed of $7.5 \mathrm{~mm} / \mathrm{s}$ and casting temperature of $730^{\circ} \mathrm{C}$, the values for the elongation are high and reach approximately 12.1-12.2\%.

In Figure 4, the common influence of the casting speed and the casting temperature on the yield strength and elongation in relation to the 

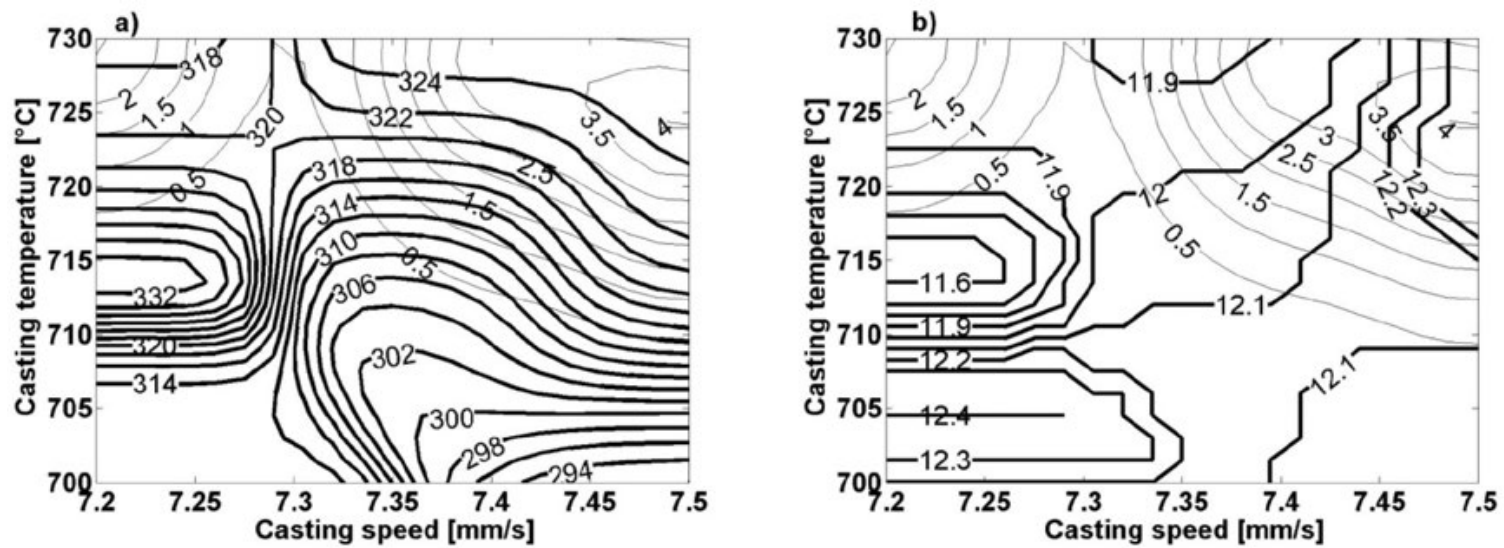

Figure 4: Common influence of casting speed and casting temperature on (a) yield strength and (b) elongation with HH1 cooling mode.

HH1 cooling mode can be seen. In the area of the diagram to the casting speed of approximately $7.29 \mathrm{~mm} / \mathrm{s}$, and above casting temperature of $714^{\circ} \mathrm{C}$ the values for the yield strength (Figure 4a) decrease with increasing values for the casting temperature and constant values for the casting speed. In the area above a casting speed of $7.3 \mathrm{~mm} / \mathrm{s}$, the values for the yield strength increase with increasing values for the casting temperature and constant values for the casting speed. At a casting speed of $7.5 \mathrm{~mm} / \mathrm{s}$ and a casting temperature of $730^{\circ} \mathrm{C}$, the values for the yield strength are a maximum and reach approximately 325-326 MPa. The values for the elongation (Figure $4 \mathrm{~b}$ ) decrease with increasing values for the casting speed and constant values for the casting temperature in the area of the diagram up to a casting speed of $7.3 \mathrm{~mm} / \mathrm{s}$ and above a casting temperature of $710^{\circ} \mathrm{C}$. At a casting temperature of $715^{\circ} \mathrm{C}$ and a casting speed of $7.23 \mathrm{~mm} / \mathrm{s}$, the values for the elongation reach a minimum of $11.6 \%$. In the same area, above a casting temperature of $715^{\circ} \mathrm{C}$, the values for the elongation increase with constant values for the casting speed and increasing values for the casting temperature. In the area of the diagram above a casting speed of 7.35 and a casting temperature of $710^{\circ} \mathrm{C}$, the values for the elongation increase with increasing values for the casting speed and constant values for the casting temperature. The highest values for the elongation are at a casting speed of $7.5 \mathrm{~mm} / \mathrm{s}$ and a casting temperature of $720^{\circ} \mathrm{C}$, reaching values of approximately $12.3-12.4 \%$.
When comparing the results of the analysis of the common influence of ram speed and extrusion ratio or casting speed and temperature on the yield strength and elongation, the influence of the PH and HH1 cooling modes can be clearly seen. The locations of the maximum values for the yield strength and elongation from Figures 1-2 are gathered in Table 3. In both cases, in Figures 1 and 2, the values for the extrusion ratio and the ram speed of the maximum values for the yield strength and the elongation are not far apart (Figure 1) or nearly coincide (Figure 2). The largest difference can be seen in the analysis in Figure 1. For an extrusion ratio of 15 and a ram speed of $14 \mathrm{~mm} / \mathrm{s}$, the values for the yield strength and elongation are high and reach approximately 323-324 MPa and 12.4$12.5 \%$, respectively, which are higher than average (Table 2). The values for the elongation are even higher at an extrusion ratio of 22 and a ram speed of $7 \mathrm{~mm} / \mathrm{s}$, reaching approximately $12.6-12.8 \%$, but the values for the yield strength are average (319-320 MPa). When cooling with the HH1 mode, the maximum values for the yield strength and elongation nearly coincide and are high at an extrusion ratio of 22 and a ram speed of $11 \mathrm{~mm} / \mathrm{s}$. The values for the yield strength and the elongation reach approximately 326-327 MPa and 12.3-12.4\%, respectively, and are higher than average (Table 2). Compared to the $\mathrm{PH}$ cooling mode, in which for an extrusion ratio of 15 and a ram speed of $14 \mathrm{~mm} / \mathrm{s}$, the values for the yield strength and elongation reach approximately 323-324 MPa and $12.4-12.5 \%$ (Table 3 ), respectively, the 
Table 3: Results for maximum values of yield strength or elongation from analysis with corresponding values for ram speed and extrusion ratio for different cooling modes.

\begin{tabular}{cccccc}
$\begin{array}{c}\text { Mode of } \\
\text { cooling }\end{array}$ & $\begin{array}{c}\text { Max. yield } \\
\text { strenght or } \\
\text { elongation }\end{array}$ & $\begin{array}{c}\text { Extrusion ratio } \\
{[/]}\end{array}$ & $\begin{array}{c}\text { Ram speed } \\
{[\mathbf{m m} / \mathbf{s}]}\end{array}$ & $\begin{array}{c}\text { Yield strength } \\
\text { [MPa] }\end{array}$ & Elongation [\%] \\
\hline \multirow{2}{*}{ PH } & Max. Y.S. & 15 & 14 & $323-324$ & $12.4-12.5$ \\
\cline { 2 - 6 } & Max. E. & 22 & 7 & $319-320$ & $12.6-12.8$ \\
\hline \multirow{2}{*}{ HH1 } & Max. Y.S. & 17 & 14 & $326-327$ & $12.3-12.4$ \\
\cline { 2 - 6 } & Max. E. & 22 & 11 & $323-324$ & $12.5-12.6$ \\
\hline
\end{tabular}

Notes: E., elongation; Min., minimum; Max., maximum; Y.S., yield strength.

Table 4: Results for maximum values of yield strength or elongation from analysis with corresponding values for casting speed and casting temperature of different cooling modes.

\begin{tabular}{cccccc}
$\begin{array}{c}\text { Mode of } \\
\text { cooling }\end{array}$ & $\begin{array}{c}\text { Max. yield } \\
\text { strenght or } \\
\text { elongation }\end{array}$ & $\begin{array}{c}\text { Casting speed } \\
{[\mathbf{m m} / \mathbf{s}]}\end{array}$ & $\begin{array}{c}\text { Casting } \\
\text { temperature } \\
{\left[{ }^{\circ} \mathbf{C}\right]}\end{array}$ & $\begin{array}{c}\text { Yield strength } \\
\text { [MPa] }\end{array}$ & Elongation [\%] \\
\hline \multirow{2}{*}{ PH } & Max. Y.S. & 7.35 & 730 & $324-325$ & $11.9-12$ \\
\cline { 2 - 6 } & Max. E. & 7.5 & 730 & $316-317$ & $12.1-12.2$ \\
\hline \multirow{2}{*}{ HH1 } & Max. Y.S. & 7.5 & 730 & $325-326$ & $12.3-12.4$ \\
\cline { 2 - 6 } & Max. E. & 7.5 & 720 & $322-324$ & $12.3-12.4$ \\
\hline
\end{tabular}

Notes: E., elongation; Min., minimum; Max., maximum; Y.S., yield strength.

values for the yield strength are higher, but the values for the elongation are lower.

In the case of the common influence of casting speed and casting temperature on the yield strength and elongation (Figures 3-4) in relation to the different cooling modes, the maximum values for the yield strength and elongation are concentrated at higher values for the casting speed and the casting temperature. The locations (casting speed and casting temperature) of the maximum values for the yield strength or the elongation from the analysis in Figures 3-4 are gathered in Table 4. In Figure 3 , the values for the casting speed and the casting temperature of the maximum values for yield strength or elongation do not coincide. At a casting speed of $7.35 \mathrm{~mm} / \mathrm{s}$ and a casting temperature of $730^{\circ} \mathrm{C}$, yield strength (324-325 MPa) is high, but the values for the elongation are only above average and reach around $11.9-12 \%$ (Table 3). On the other hand, at a casting speed of $7.5 \mathrm{~mm} / \mathrm{s}$ and a casting temperature of $730^{\circ} \mathrm{C}$, the values for elongation (12.1-12.2\%) are higher, but the values for the yield strength reach approximately 316-317 MPa, which are less than the average values (Table 2). But in Figure 4, with the HH1 cooling mode, high values for the yield strength and elongation coincide at a casting speed of
$7.5 \mathrm{~mm} / \mathrm{s}$ and a casting temperature of $730^{\circ} \mathrm{C}$. At this point, the values for the yield strength and elongation reach approximately 325$326 \mathrm{MPa}$ and $12.3-12.4 \%$, respectively, which are higher than the average values (Table 2). In comparison to the $\mathrm{PH}$ mode of cooling, where the optimal values for yield strength and elongation reach approximately 323-324 $\mathrm{MPa}$ and $11.9-12 \%$, respectively, at a casting speed of $7.4 \mathrm{~mm} / \mathrm{s}$ and a casting temperature of $730^{\circ} \mathrm{C}$, the values for the yield strength and elongation are higher when cooling with the HH1 mode.

\section{Conclusions}

From the result of the analysis for the common influence of ram speed and extrusion ratio or casting speed and casting temperature on the yield strength and elongation for different cooling modes, the following conclusions can be drawn:

- The cooling mode in relation to the extrusion ratio and ram speed, or casting speed and casting temperature, has a complex influence on the yield strength and elongation.

- In the analysis of the common influences of ram speed and extrusion ratio, the 
PH mode of cooling gives higher optimal values of 12.4-12.6 for the elongation and lower values of 323-324 MPa for the yield strength. The HH1 cooling mode gives higher values for the yield strength (326-327 MPa) but lower values for the elongation (approximately 12.3-12.4\%), compared to the PH cooling mode. In both cooling modes, the areas with above-average values for the yield and elongation can be found and are concentrated in the same area, at an extrusion ratio of approximately 15 and a ram speed of approximately $14-17 \mathrm{~mm} / \mathrm{s}$.

- The maximum values for the yield strength and elongation are concentrated at higher values of the casting speed and casting temperature, i.e. around $7.35-7.5 \mathrm{~mm} / \mathrm{s}$ and $720-730^{\circ} \mathrm{C}$, respectively.

- When comparing the results of different cooling modes in relation to the common influence of the casting speed and the casting temperature, the HH1 mode of cooling is better than the PH mode of cooling. At a casting speed of $7.5 \mathrm{~mm} / \mathrm{s}$ and a casting temperature of $730^{\circ} \mathrm{C}$, the values for the yield strength and elongation are above average and reach approximately 325-326 MPa and 12.3-12.4\%, respectively.

- In order to maximise the values for the yield strength and elongation, the values for the ram speed, extrusion ratio, casting speed and casting temperature should be optimised in relation to the cooling mode.

\section{References}

[1] Hägele, N., Sonsino, C.M. (2014): Structural durability design recommendations for forged automotive aluminium chassis components submitted to spectrum and environmental loadings by the example of a tension strut. International Journal of Fatigue, 69, pp. 63-70.

[2] Mistakidis, E.S., De Matteis, G., Formisano, A. (2007): Low yield metal shear panels as an alternative for the seismic upgrading of concrete structures. Advances in Engineering Software, 38(9), pp. 626-636.

[3] Hirth, S.M., Marshall, G.J., Court, S.A., Lloyd, D.J. (2001): Effects of Si on the aging behaviour and form- ability of aluminium alloys based on AA6016. Materials Science and Engineering A, 319-321, pp. 452-456.

[4] Garrett, R.P., Lin, J., Dean, T.A. (2005): An investigation of the effects of solution heat treatment on mechanical properties for AA 6xxx alloys: experimentation and modelling. International Journal of Plasticity, 21, pp. 1640-1657.

[5] Zhang, L.Y., Jiang, Y.H., Ma, Z., Shan, S.F., Jia, Y.Z., Fan, C.Z., Wang, W.K. (2008): Effect of cooling rate on solidified microstructure and mechanical properties of aluminium-A356 alloy. Journal of Materials Processing Technology, 207, pp. 107-111.

[6] Zhang, X.H., Su, G.C., Ju, C.W., Wang, W.C., Yan, W.L. (2010): Effect of modification treatment on the microstructure and mechanical properties of $\mathrm{Al}-$ 035\% Mg-7.0\%Si cast alloy. Materials \& Design, 31(9), pp. 4408-4413.

[7] Lendvai, J. (1996): Precipitation and strengthening in aluminium alloys. Material Science Forum, 217-222, pp. 43-56.

[8] Wang, E.R., Hui, X.D., Wang, S.S., Zhao, Y.F., Chen, G.L. (2010): Improved mechanical properties in cast $\mathrm{Al}-\mathrm{Si}$ alloys by combined alloying of $\mathrm{Fe}$ and $\mathrm{Cu}$. Materials Science and Engineering A, 527(29-30), pp. 78-84.

[9] Birol, Y. (2006): The effect of processing and Mn content on the T5 and T6 properties of AA6082 profiles. Journal of Materials Processing Technology, 173, pp. 84-91.

[10] Mrowka-Nowotnik, G., Sieniawski, J. Nowotnik, A. (2005): Effect of heat treatment on tensile and fracture toughness properties of 6082 alloy. Journal of Materials Science and Engineering, 163, pp. 367-372.

[11] Sjolander, E., Seifeddine, S. (2010): The heat treatment of Al-Si-Cu-Mg casting alloys. Journal of Materials Processing Technology, 210, pp. 1249-1259.

[12] Mrowka-Nowotnik, G., Sieniawski, J. (2005): Influence of heat treatment on the microstructure and mechanical properties of 6005 and 6082 aluminium alloys. Journal of Materials Processing Technology, 163, pp. 367-372.

[13] Liu, Y.L., Kang, S.B., Kim, H.W. (1999): The complex microstructures in as-cast Al-Mg-Si alloy, Materials Letters, 41, pp.167-272.

[14] Mrowka-Nowotnik, G., Sieniawski, J., Wierzbińska, M. (2007): Intermetallic phase particles in 6082 aluminium alloy. Archives of Materials Science and Engineering, 28(2), pp. 69-76.

[15] Poletti, C., Wójcik, T., Sommitsch, C. (2012): Hot deformation of AA6082 Containing fine intermetallic particles. Metallurgical and Materials Transactions A, 44, pp. 1577-1586. 
[16] Dobrzański, L.A., Sitek, W. (1999): Designing of the chemical composition of constructional alloy Steels. Journal of Materials Processing Technology, 89-90, pp. 467-472.

[17] Guo, Z., Sha, W. (2004): Modelling the correlation between processing parameters and properties of maraging steels using artificial neural network. Computational Materials Science, 29, pp. 12-28.

[18] Capdevila, C., Garcia-Mateo, C., Caballero, F.G., Garcıa de Andres, C. (2006): Neural network analysis of the influence of processing on strength and ductility of automotive low carbon sheet steels. Computational Materials Science, 38, pp. 192-201.
[19] Terčelj, M., Fazarinc, M., Kugler, G., Peruš, I. (2013): Influence of the chemical composition and process parameters on the mechanical properties of an extruded aluminium alloy for highly loaded structural parts. Construction and Building Materials, 44, pp. 781-791.

[20] Večko-Pirtovšek, T., Peruš, I., Kugler, G., Terčelj, M. (2009): Towards improved reliability of the analysis of factors influencing the properties on steel in industrial practice. ISIJ International, 49(3), pp. 395-401.

[21] Peruš, I., Poljanšek, K., Fajfar, P. (2006): Flexural deformation capacity of rectangular RC columns determined by the CAE method. Earthquake Engineering \& Structural Dynamics, 35(12), pp. 1453-1470. 
